\title{
Food Distribution Application for Disaster Response
}

\author{
Ali Asghar ${ }^{1} \mid$ Dr. Bhoomi Gupta $T^{2}$ \\ 1UG student, IT, Maharaja Agrasen Institute of Technology, Delhi, India \\ ${ }^{2}$ Asst. Prof., IT, Maharaja Agrasen Institute of Technology, Delhi, India
}

\section{To Cite this Article}

Ali Asghar and Dr. Bhoomi Gupta T, "Food Distribution Application For Disaster Response", International Journal for Modern Trends in Science and Technology, 6(12): 141-146, 2020.

\section{Article Info}

Received on 08-November-2020, Revised on 28-November-2020, Accepted on 02-December-2020, Published on 05-December-2020.

\section{ABSTRACT}

Food Distribution Application For Disaster Response is one of the innovative and contemporary topic in these days that consider to be esteemed idea. This project is based on the distribution of food items to the needy ones who struck at disaster prone area with the help of drone (Unmanned Aerial Vehicle).This drone is handled by remote control by a human operator. It can be operated remotely in real-time or pre-programmed to fly independently on the pre-defined routes. This drone has Bluetooth in-built through which it can be connected with people who afflicted in a disaster prone area. Drone has camera in-built through which it captures the picture of calamity area. This application has the functionality that it alarms the nearby people or government relief workers so that people may vacate from the catastrophic area. This paper presents a systematic review of contributions on relief distribution networks in response to disaster.

KEYWORDS: Food Distribution Application For Disaster Response, Unmanned Aerial Vehicle, catastrophic , Bluetooth, remote

\section{INTRODUCTION}

As far as this project concern, This project is gonna really helpful for our society at the time of disaster struck that particular area. This application has various functionalities through which people may get a lot of benefit and indeed really helpful for our esteemed citizens. By using this application so many of the NGO and nearby people will give so much of help to the victims of disaster struck area. As the disaster struck the area government would disperse a lot of amount but couldn't delivery the basic things to make them alive. Food security is one of the major priorities of all countries around the world.

This application can be used as a user guide to know about natural disasters, man made disasters, disaster management life cycle, emergency kit etc.
It includes details of help line centre with in-built calling feature. Natural disasters create a great danger to food security.

In this project the delivery of food is done using Android Apps. Android Applications can be written using Kotlin, Java and C++ languages. But in this project I use Java language because it is straight forward and readable syntax. It has no operator overloading and no extension functions. Framework that I used is Native Android Framework. The Android SDK tools compile our code along with any data and resource files into an APK, an Android

Package, which is an archive file with an apk suffix. One APK file contains all the contents of an android app and is the file that Android-powered devices use to install the app. App components are 
the essential building blocks of an Android app.

Each component is an entry point through which the system or a user can enter our app.
2. Services

3. Broadcast Receivers

4. Content providers

There are four different types of app components:

\section{RELATED WORK}

1. Activities

\begin{tabular}{|c|c|c|c|c|c|}
\hline ProjectName & Authors & Date OfPublish & Methodology & Objective & Conclusion \\
\hline $\begin{array}{l}\text { 1. Relief } \\
\text { Distributions } \\
\text { Networks: A } \\
\text { Systematic Review }\end{array}$ & $\begin{array}{l}\text { Ana Maria } \\
\text { Anaya-Arenas } \\
\text { Jacques } \\
\text { Renaud, } \\
\text { Angel Ruiz }\end{array}$ & $\begin{array}{l}\text { - Decemb } \\
\text { er } 2014\end{array}$ & $\begin{array}{l}\text { It pursues three } \\
\text { goals. First, to } \\
\text { conduct an } \\
\text { up-to-date survey of } \\
\text { the research in } \\
\text { relief distribution } \\
\text { networks focusing } \\
\text { on the logistics } \\
\text { aspects of the } \\
\text { problem. }\end{array}$ & $\begin{array}{l}\text {, the study of } \\
\text { relief } \\
\text { distribution } \\
\text { networks has } \\
\text { become one of } \\
\text { the most } \\
\text { popular topics } \\
\text { within the } \\
\text { Emergency } \\
\text { Management } \\
\text { field. In fact, the } \\
\text { number and } \\
\text { variety of } \\
\text { contributions } \\
\text { design. }\end{array}$ & $\begin{array}{l}\text { Analyzed the } \\
\text { possible } \\
\text { context-specific } \\
\text { and individual } \\
\text { and formulates } \\
\text { that this relief } \\
\text { distribution } \\
\text { network will be } \\
\text { big impact on } \\
\text { the level } \\
\text { Ground } \\
\text { ultimately . }\end{array}$ \\
\hline $\begin{array}{l}\text { 3. Food Network } \\
\text { Resilience Against } \\
\text { Natural Disasters: } \\
\text { A Conceptual } \\
\text { Framework }\end{array}$ & $\begin{array}{l}\text { 1.Muhammad } \\
\text { Umar } \\
\text { 2. Mark } \\
\text { Wilson } \\
\text { 3.Jeff Heyl }\end{array}$ & $\begin{array}{l}\text { First } \\
\text { Published July } \\
7,2017\end{array}$ & $\begin{array}{l}\text { The main purpose } \\
\text { of this research is to } \\
\text { develop an } \\
\text { integrated } \\
\text { framework for food } \\
\text { supply chain } \\
\text { resilience especially } \\
\text { in the advent of } \\
\text { natural disasters. }\end{array}$ & $\begin{array}{l}\text { We propose a } \\
\text { conceptual } \\
\text { framework that } \\
\text { highlights the } \\
\text { importance of } \\
\text { logistics, } \\
\text { collaboration, } \\
\text { sourcing, and } \\
\text { knowledge } \\
\text { management in } \\
\text { achieving } \\
\text { supply chain } \\
\text { resilience. }\end{array}$ & $\begin{array}{l}\text { The } \\
\text { experiments } \\
\text { showed that the } \\
\text { This application } \\
\text { provide the } \\
\text { utmost relief by } \\
\text { giving the food } \\
\text { to the needy } \\
\text { ones. }\end{array}$ \\
\hline $\begin{array}{l}\text { 4.MS research } \\
\text { perspectives in } \\
\text { disaster } \\
\text { operations } \\
\text { management }\end{array}$ & $\begin{array}{l}\text { 1.Henry Lamo } \\
\text { s Diaz } \\
\text { 2. } \\
\text { Karin Aguilar } \\
\text { Imitola } \\
\text { 3.Rolando } \\
\text { José Acosta } \\
\text { Amado }\end{array}$ & $\begin{array}{l}\text { Apr/June } 201 \\
9\end{array}$ & $\begin{array}{l}\text { To develop this } \\
\text { review, we consider } \\
\text { the classification } \\
\text { scheme used by and } \\
\text { later by, excluding } \\
\text { the dimension of the } \\
\text { classification. }\end{array}$ & $\begin{array}{l}\text { The } \\
\text { unpredictability } \\
\text { of natural } \\
\text { disasters makes } \\
\text { handling their } \\
\text { impacts on the } \\
\text { population, the } \\
\text { environment } \\
\text { and the } \\
\text { economic a } \\
\text { resources } \\
\text { challenging } \\
\text { decision-makin } \\
\text { g process that } \\
\text { must be wisely } \\
\text { performed in a } \\
\text { very short } \\
\text { period of time. }\end{array}$ & $\begin{array}{l}\text { The task of } \\
\text { discriminating } \\
\text { obtain an } \\
\text { average } \\
\text { accuracy } \\
\text { encouraging } \\
\text { result } \\
\text { considering the } \\
\text { difficulty of the } \\
\text { problem. }\end{array}$ \\
\hline
\end{tabular}




\begin{tabular}{|c|c|c|c|c|c|}
\hline $\begin{array}{l}\text { 5. Using Mobile } \\
\text { Phone Data for } \\
\text { Emergency } \\
\text { Management: a } \\
\text { Systematic } \\
\text { Literature Review }\end{array}$ & $\begin{array}{l}\bullet \\
\text { Wang, Yanxin } \\
\text { Li, Jian } \\
\text { - Xi } \\
\text { Zhao, } \\
\text { G Gengz } \\
\text { hong Feng \& } \\
\text { - Xin } \\
\text { (Robert) Luo }\end{array}$ & $\begin{array}{l}\text { - } \quad \text { Publish } \\
\text { ed: } 16 \\
\text { September } \\
2020\end{array}$ & $\begin{array}{l}\text { Many studies have } \\
\text { regarded mobile } \\
\text { phone data as a } \\
\text { potential data } \\
\text { source to fulfill } \\
\text { these requirements, } \\
\text { because these data } \\
\text { reflect human } \\
\text { behavior richly and } \\
\text { ubiquitously. }\end{array}$ & $\begin{array}{l}\text { Emergency } \\
\text { management } \\
\text { (EM) has always } \\
\text { been a concern } \\
\text { of people from } \\
\text { all walks of life } \\
\text { due to the } \\
\text { devastating } \\
\text { impacts } \\
\text { emergencies } \\
\text { can have. The } \\
\text { global outbreak } \\
\text { of COVID-19 in } \\
\text { 2020 has } \\
\text { pushed EM to } \\
\text { the top topic. }\end{array}$ & $\begin{array}{l}\text { The technique } \\
\text { is applied to } \\
\text { describe the } \\
\text { geometry of a } \\
\text { given structure. }\end{array}$ \\
\hline $\begin{array}{l}6 . \quad \text { Promoting } \\
\text { built-for-disaster- } \\
\text { purpose mobile } \\
\text { applications: An } \\
\text { interdisciplinary } \\
\text { literature review } \\
\text { to increase their } \\
\text { penetration rate }\end{array}$ & $\begin{array}{l}\text { Aliperti G, } \\
\text { Cruz A }\end{array}$ & $\begin{array}{l}\begin{array}{l}\text { Date } \\
\text { publication }\end{array} \\
\text { 23 Jul } 2020\end{array}$ & $\begin{array}{l}\text { - We systematically } \\
\text { reviewed } \\
\text { interdisciplinary } \\
\text { academic } \\
\text { contributions to } \\
\text { analyze research on } \\
\text { apps-users' } \\
\text { intention to adopt } \\
\text { mobile applications }\end{array}$ & $\begin{array}{l}\text { This study } \\
\text { focuses on the } \\
\text { promotion and } \\
\text { use of } \\
\text { tourist-oriented } \\
\text { built-for-disaste } \\
\mathrm{r} \quad \text { purpose } \\
\text { mobile } \\
\text { applications. }\end{array}$ & $\begin{array}{l}\text { Compressively } \\
\text { study the fusion } \\
\text { of different } \\
\text { layers and } \\
\text { manifest it } \\
\text { shows that this } \\
\text { application is } \\
\text { really } \\
\text { impressive due } \\
\text { to innovative } \\
\text { technique. }\end{array}$ \\
\hline
\end{tabular}

\section{METHODOLOGICAL APPROACH}

The basic idea of the android application we are visiting make is that users are going to be ready to get notifications at the time of any calamity like earthquakes, floods and hurricanes by getting alerts from anyone who gets to understand of the calamity quickly by getting a notification within the type of images posted online or any common text broadcasts in keeping with their location and provide the food as soon as possible to the victims of that exact affected areas. In addition to the current, within the case of earthquake, our application will make use of the gyroscopic sensor and accelerometer of the smartphone of the user in step with the continous period of your time. Once the user is informed of the calamity, the user follows the emergency steps to be taken during the time of the calamity. We also incorporate government agencies to notify just in case of a hurricane or flood beforehand through the applying and also provide various fast access emergency number within the application. Our idea stems from the actual fact that when a calamity comes, it's the people near the calamity area that get notified of the calamity first not the news channel so therefore through the means of the people we notify all others within the surrounding areas to act accordingly. We also take help from the govt. agencies who can create a special account in our application to specifically notify just in case of an incoming danger. The food items are going to be deliver by Unmanned Aerial Vehicle which is additionally referred to as Drone. It combines a digitically airframe with in-built software that permits an Android Smartphone on the bottom to regulate the one fastened onto the airframe via Bluetooth. 
InTormation systems Arcnitecture

for Disaster Management

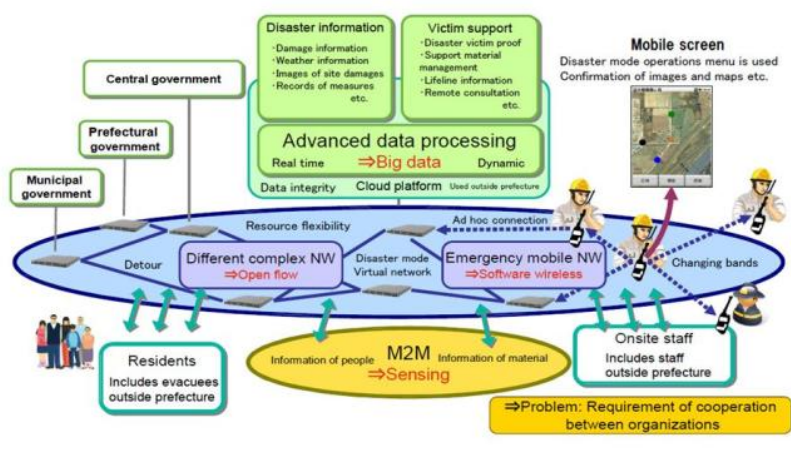

DATA FLOW DIAGRAM

\section{FLOW OF STEPS CONSIDER FOR THE PROJECT COMPLETION}

1. First and the foremost step is to collect the data from various sources that is required for the training and test modules of our dataset. The data collected is in raw format and cannot be usedas direct.

2. After the completion of data formatting the labels of each image is to be copied from the internet explorer.

3. An overview of the Android Operating System (OS) and a classification of Android malware, understanding the code and permission level features that are responsible for malicious activities.

4. A survey of literature work intended to mitigate malware activities during application development and deployment stages, discuss the importance of mobile device security and user information, outline common vulnerabilities in mobile applications.

5. The project also addresses the stated research question by performing an in-depth study of food supply for needy ones during natural calamity.

6. With the help of UAV the transportation of food could be done.

7. In order to making the UAV this application works so perfectly to fulfill the needy problems that struck in disaster.
8. UAV is handled by the man to show or directing the direction in which direction drone has to go.

9. The model is now to show the best accuracy which helps the needy one.

10. Number of times code is repeated to perform the application in a best way.

\section{ANDROID APPLICATION ARCHITECTURE}

Android architecture is a software stack of components to support mobile device needs. Android software stack contains a Linux Kernel, collection of $\mathrm{c} / \mathrm{c}^{++}$libraries which are exposed through an application framework services, runtime, and application.

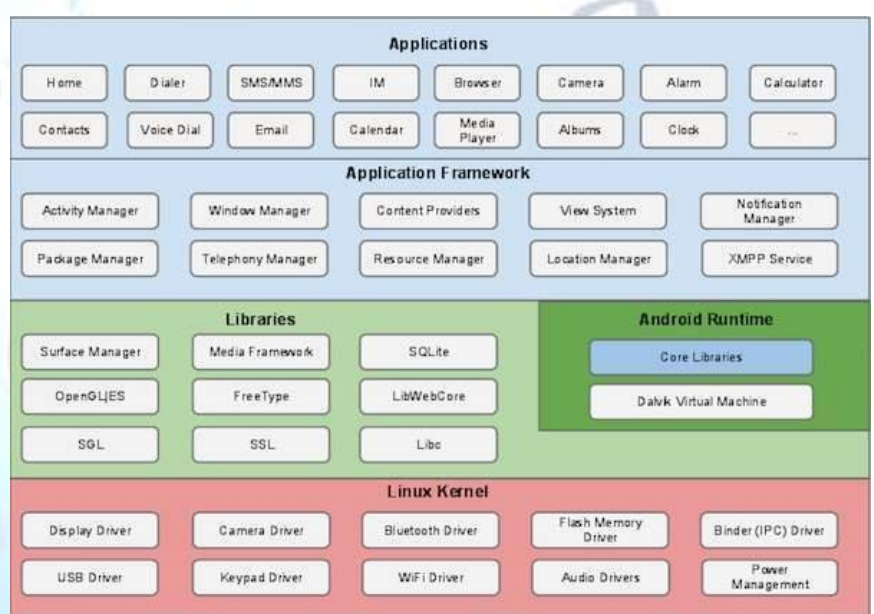

In order to create an android application we are using Android Studio platform . Android Studio consistently made its position on top of the table. It's very powerful software, offering the latest tools and plug-ins to create complex applications.

Google made Android Studio in 2013. Among other Android App Development tools this software claims to have more attention from developers across the globe.

Android Studio has so many features such as:

1.Insightful code proofreader

2.Quick and Responsive Emulator

3.NDK Support

Android Studio has many advantages such as:

1.Powerful Testing Tools

2.Powerful Adaptable

3.Cloud\&Firebase connectivity

Overview of Android Studio Platform 

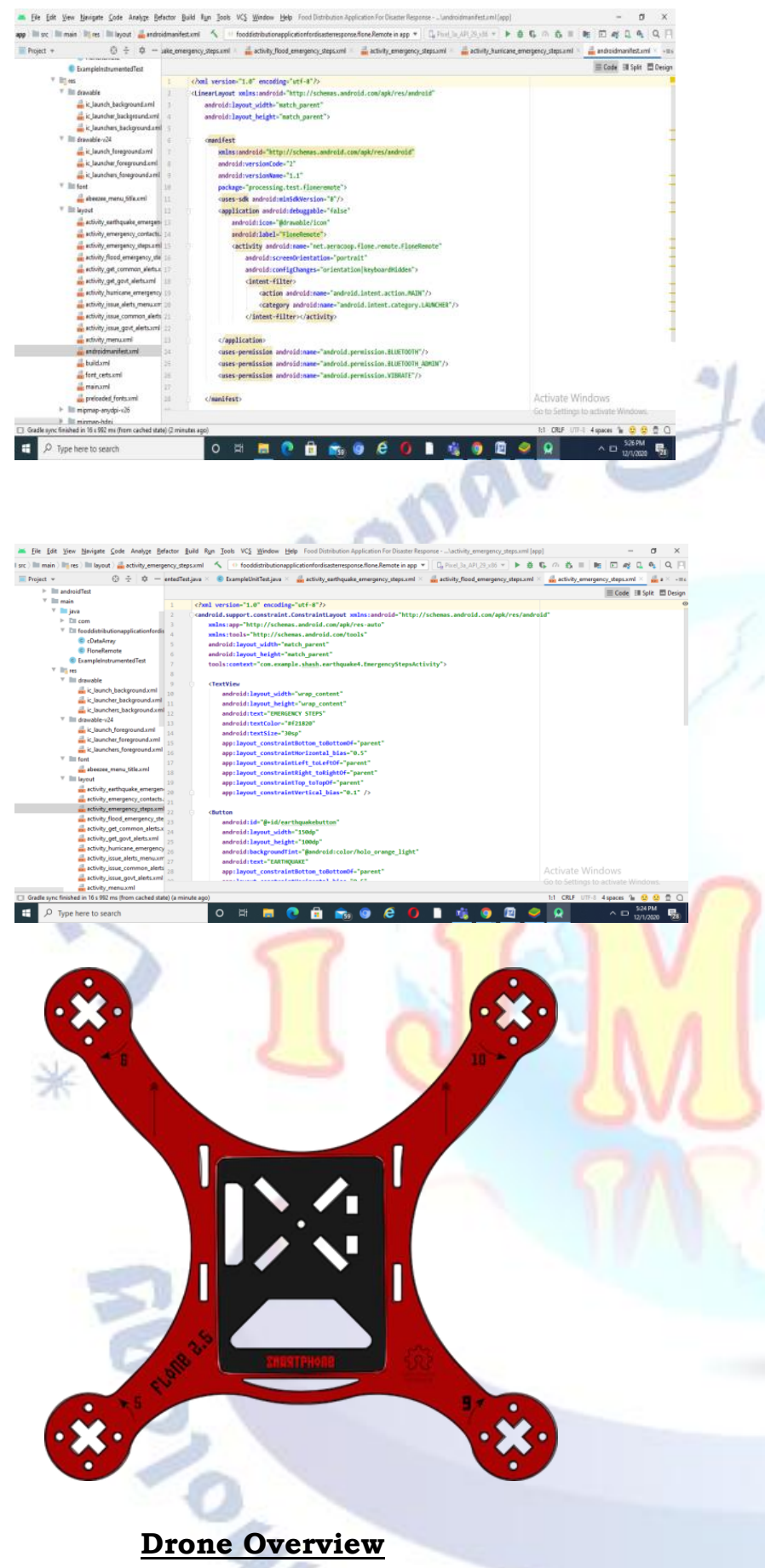

\section{RESULTS}

This application designed system makes it easier to monitor the drone throughout the process of delivering the food items to those persons who stuck in natural calamity areas.

As soon as the disaster struck the emergency contact details of the government or NGO'S available in this application to rescue the victims of disaster.

This application fulfills the basic need of people by supplying the essential food items immediately. Their will be a separate Bluetooth system in-built in this device to identify the location at exact place.

\section{CONCLUSION}

In this paper we came to a conclusion that this application will be really helpful indeed at the time of disaster comes to be at any place. We are trying to make them people aware through this application so as soon as people get to know the present scenario of that particular area. This application accomplishes the basic food items which is at utmost requirement. The possibility of extension in this application is so wide to take the help on the ground situation as well.

\section{REFERENCES}

[1] Chen, Y., Crespi, N., Ortiz, A. M., \& Shu, L. (2017). Reality mining: A prediction algorithm for disease dynamics based on mobile big data. Information Sciences, 379, 82-93. https://doi.org/10.1016/j.ins.2016.07.075.

[2] Cheong, M., \& Lee, V. C. S. (2011). A microblogging-based approach to terrorism informatics: Exploration and chronicling civilian sentiment and response to terrorism events via twitter. Information Systems Frontiers, 13(1), 45-59.

[3] Cinnamon, J., Jones, S. K., \& Adger, W. N. (2016). Evidence and future potential of mobile phone data for disease disaster management. Geoforum, 75, 253-264. https://doi.org/10.1016/j.geoforum.2016.07.0 $\underline{19}$.

[4] Cozzens, T. (2020). 19 countries track mobile location to fightCOVID-19. https://www.gpsworld.com/19-countrie s-track-mobile-locations-to-fight-covid-19/. Accessed 29 July 2020.

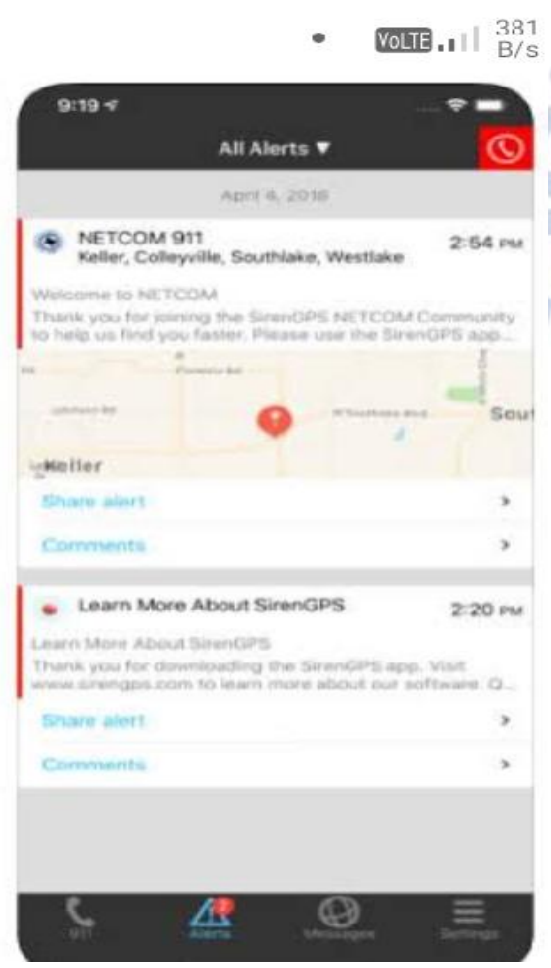

Overview of Emulator 